\title{
遠隔期川崎病既往者における冠動脈病変と成人期の 急性冠症候群：小児循環器の立場から
}

\author{
三谷 義英
}

\begin{abstract}
Yoshihide Mitani: Sequelae long after Kawasaki disease and the risk for acute coronary
\end{abstract} syndrome in adulthood: pediatric cardiology perspective. J Jpn Coron Assoc 2013; 19: 179-183

I. はじめに

1967 年に川崎病が報告されてから 45 年余りが経過し, 川崎病既往者 27 万名のうち 11 万名余りが 20 歳以上の成 人期に達し 11 , 近い将来に川崎病既往者の過半数が成人例 となることが予想されている，最近では，成人期に新た に急性冠症候群を発症する例が少数ながら報告される様 になり，その中で小児期から成人期に至る診療中断のな い診療体制, 成人期の予後と管理の問題が明らかになり つつある。一方, 大量ガンマグロブリン療法の導入後, 心合併症の発症率は低下傾向にあるが, 特に問題となる 巨大冠動脈瘤は依然として認められ，川崎病の罹患率は 近年むしろ増加傾向にあることから, 川崎病既往児の冠 動脈合併症への対応は, 小児期, 成人期診療において今 後の重要な課題であるといえる2).

実際の内科診療の現場において，長期経過した川崎病 既往児に対応する機会は決して少なくないと思われる. 川崎病既往成人例の小児科からの診療移行例, 冠イベン 卜例での鑑別の機会，また一次診療の現場では，小児循 環器施設との平行した経過観察, 学校管理, 服薬等のか かりつけ医としての対応が必要とされ，最近は長期予後 に関しての相談の機会も多いと思われる，以上から，川 崎病既往者の診療において, 小児科と内科の連携が重要 となってきている.

本稿では, 小児科, 内科の診療現場の問題として, (1)主 に小児期後遺症管理に関連する冠後遺症の分類, 自然歴, 管理をガイドラインに則して概説し，(2)最近関心の高い， 成人例の急性冠症候群のリスクと内科への診療移行の問 題, (3)後遺症なし例の対応について, ガイドラインに則し た具体的な対応，最近のエビデンスに関して報告する。な お後遺症管理の詳細, 冠合併症以外に関しては, 日本川崎

三重大学大学院医学系研究科小児科学 ( ⿳ 厂 514-8507 三重県津市 江戸橋 2-174)

doi: $10.7793 /$ jcoron. 19.017
病研究会 $\left(2002\right.$ 年) ${ }^{3)}$, 日本循環器学会ガイドライン (2008 年) ${ }^{4)}$, 米国心臓学会ガイドライン AHA20045), AHA20066)を参照されたい.

\section{II. 小児科領域での川崎病後冠後遺症の自然歴と 診療の考え方}

\section{1. 冠後遺症の分類と自然歴}

川崎病後 30 病日以降に残存した冠動脈瘤の分類とし て, 小動脈瘤, 中等瘤, 巨大瘤に分類される。また長期 経過後の重症度分類として, 拡大性変化がなかった群, 急性期の一過性拡張群, regression 群, 冠動脈瘤残存群, 冠動脈狭窄性病変群 $(\mathrm{a}$ ：虚血所見のない群, $\mathrm{b}$ ：虚血所見 を有する群)に分類される (Table 1) ${ }^{4)}$ ，冠動脈瘤は，瘤が 消失し造影上正常化するいわゆる退縮(regression) と呼ば れる現象が 32〜 $50 \%$ に認められ, 発症 1〜2 年以内に小中等瘤で起こることが多く，巨大瘤では稀である。病理 学的には, 平滑笳細胞の遊走, 増殖による内膜肥厚によ るとされている. $75 \%$ 以上の有意な局所性狭窄は, 対象 の重症度, 経過年数によるが, 4.7〜 12\%に認められ, 動 脈瘤の流入部と流出部に発症し, 求心性内膜肥厚による と考えられている. 左冠動脈, 特に主幹部, 左前下行枝 近位部に多く，巨大瘤，狭窄に進行することが多いとさ れ, $6.0 \mathrm{~mm}$ 以上の中等瘤 (最低 $5.6 \mathrm{~mm}$ ) でも狭窄が出現す ることはあると報告される。また左冠動脈の局所性狭窄 は，10 年以上の長期経過観察後に出現することも報告さ れ，長期の経過観察が重要である。動脈瘤の閉塞は，中 等瘤以上で $16 \%$ に出現し, その多くは 2 年以内に出現し た.これらは, 心筋梗塞, 突然死に繋がることもある が，無症状が $2 / 3$ で認められたと報告される。 巨大瘤で は， 1 年以内に $20 \%$ に急性冠イベントが認められたと報 告される。閉塞後再疎通像は，セグメント狭窄とも呼ば れることがあるが, 冠動脈障害例の $15 \%$ にられ，その 90\%は右冠動脈であり, 右冠動脈は閉塞しやすく再疎通 しやすいとされる。 
J Jpn Coron Assoc 2013; 19: 179-183

Table 1 川崎病心臓血管病変の重症度分類 $\left(\mathrm{JCS} 2008^{4)}\right.$ から抜粋 $)$

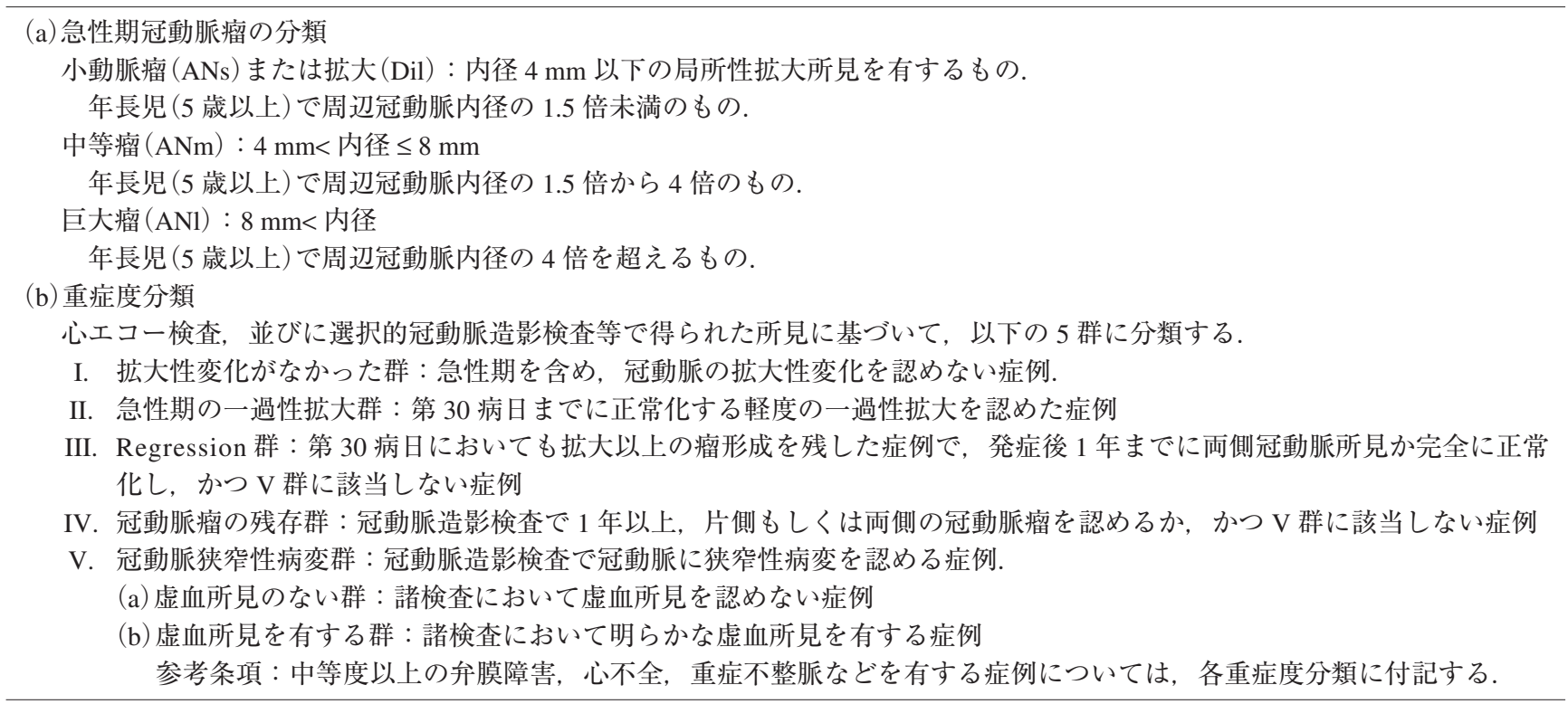

\section{2. 診療}

心エコー検査は, 非侵襲性, 簡便性から最も一般的に 行われるものであり, 川崎病冠動脈病変の特徵的所見で ある冠動脈拡大性病変に対しては経時的に冠動脈の形態 評価を行うことができる4). 成人例では, 冠動脈瘤を描出 することによって川崎病の診断をされることがある。ま た，冠動脈瘤を認める場合には，瘤内血栓の有無をある 程度診断することができる。しかし, 狭窄性病変, 閉塞 の評価は困難なことが多く, 本症のエコー診断には限界 がある. そこで従来から選択的冠動脈造影が, 川崎病後 冠動脈障害のゴールドスタンダードとされ, 中等瘤以上 では回復期早期に冠動脈造影により, 冠動脈障害の形 態, 範囲を詳細に把握しておくことが, 後の経過観察の 手段, 期間, 治療法の決定などのために望ましいとされ ている. 巨大瘤の場合, 諸検査で心筋虚血所見がなくて も, 重篤な局所性狭窄が出現していることがあるため, 遠隔期においても数年ごとの冠動脈造影が望ましいとさ れている. しかし, 最近 MDCT, MRIによる正確な冠動 脈狭窄病変の評価が可能となりつつあり, 診断のための カテーテルが今後省略できる症例も出てくると思われ る。しかし, MDCTに打いては, 放射線被曝, 徐脈化の ための $\beta$ 遮断薬の使用, 息止め, 石灰化の狭窄度評価へ の影響などの問題があるが, 多列化などのソフト, ハー ドの改善が期待される. MRI は, X 線被曝がなく, 自然 呼吸下で施行可能で, 徐脈化も不必要なため低年齢児で も期待される. また, 薬物負荷パーフュージョン MRIに より, 心筋虚血, 梗塞, 心筋 viability の評価に有用であ る. 一層の普及にはソフト, ハードの改善が期待され る. しかし, MRIがRI 検査に比べより鋭敏に虚血, 梗塞 を評価し得ることが多数報告され， RI 検査に伴う被曝の
問題がクリアされるために, 今後心筋虚血, 梗塞の評価 法は変わるかも知れない. 特に年長児, 成人例では, 経 過観察中に瘤が退縮し内膜肥厚は残存しても造影上は正 常な血管所見となり退縮とみなされた病変が, MDCT, MRIにより, 壁病変の形態, 構成成分 (石灰化など) も含 めた評価が可能となりつつあり, その役割が注目される.

薬物療法に関しては, 冠動脈瘤形成例では, 虚血性心 疾患の予防, 血小板の活性化による血栓形成助長の予防 目的で, 抗血小板薬が継続して投与される.これにより 狭心症や心筋梗塞の発症頻度の抑制がはかられる。ワー ファリンなど抗凝固薬は, 巨大冠動脈瘤形成例および瘤 内血流うっ滞例, 瘤内血栓エコー例, 急性心筋梗塞発症 既往例である. ほかに狭心症例には, 病態に応じてカル シウム拮抗薬, $\beta$ 遮断剂, 硝酸剤が投与され, 心機能低下 例には，抗心不全治療が行われる。

生活管理では, 病初期から正常例, 退縮例, 小動脈 瘤, 狭窄性病変 - 心筋虚血のない中等瘤は, 通常運動制限 はなく, $\mathrm{E}$ 可で管理される, 小動脈瘤, 中等瘤は, 退縮し ない場合は, 年 1 回ないしそれ以上の経過観察がなされ る. 狭窄性病変のない巨大瘤が残存した場合は, 運動部 活動への参加は禁止し，D禁ないし発症後変化のない場 合は $\mathrm{E}$ 禁もありえる. 狭窄病変, 心筋虚血を伴う例で は, 運動制限が必要で, 管理区分 D 禁以上となる。心筋 梗塞既往例は, 運動部の制限が望ましく, 病態により $\mathrm{A} \sim \mathrm{E}$ 管理となる.

\section{III. 成人例の急性冠症候群のリスク, 診療移行}

\section{1. 現時点での考え方}

川崎病血管炎の後遺症である川崎病後冠後遺症は, 一 般成人の動脈硬化に伴う涫腫と病理学的に大きく異な 
る.しかし, 川崎病の病理所見, 血管内エコー所見か ら, 冠動脈瘤, 狭窄病変には内膜肥厚が認められ, 冠動 脈障害を有する川崎病既往成人への早期動脈硬化発症の 可能性が危惧される4,7).

したがって, 動脈の瘤や狭窄性病変など明らかな冠後 遺症を有している川崎病既往例では，生涯にわたり肥 満, 高血圧, 喫煙, 糖尿病, 高コレステロールなどの生 活習慣病の危険因子に関する生活指導は意味のあること と考えられている。しかし，成人期川崎病既往者の急性 冠イベントの実態は不明であり，エビデンスに基づいた 評価法，薬物療法を含む内科的管理の確立などは今後の 検討課題であり, 小児科から内科への絶え間ない診療移 行, 内科と小児科のコラボレーションなども今後の課題 と考えられる。

小児期の経験を踏まえて作成された現時点での川崎病 既往成人の管理の要点を示す.

a. 冠動脈瘤はあるが無症状

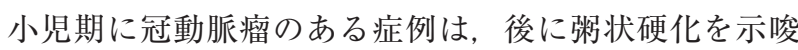
する所見を認める例が剖検心, virtual histology 血管内工 コー法などの小規模研究で報告されている.川崎病によ る冠動脈瘤が寛解し冠動脈造影上正常でも血管内超音波 や薬物の反応性に異常を認めることより，成人でも動脈 硬化の危険因子となり得ることから, 長期経過観察が必 要である。したがって，長期間の心危険因子層別化や管 理が必要である，成人期にも冠動脈瘤があるが無症状の 症例でも, 毎年 $2 \sim 3$ 回の非侵襲的な検査と数年に 1 回の 冠動脈造影検査が望ましいと記載される。抗血小板薬の 内服を原則とし, 冠危険因子の管理が必要と考えられて いる.

b. 成人期に有症状(狭心症, 心筋梗塞, 心不全, 重症不 整脈)

成人期に狭心症，心筋梗塞，心不全掞よび重症不整脈 のある症例は, 川崎病由来ではない場合と同様の経過観 察が必要である。定期的診察と年 3〜4 回の非侵襲的な検 查のほかに, 適宜冠動脈造影検査を施行することが望ま しい.

c. 川崎病既往が不明な冠動脈瘤症例

川崎病が報告されて今だ 45 年余りであることから，内 科領域の患者を対象に川崎病既往歴を正確に聴取するこ とは困難なことも多い。そこで, 症例ごとに他の二次性 冠動脈瘤病変を有する例を除外できれば川崎病後遺症と して診断されることも多い. 基本的には若年成人で冠動 脈瘤のある症例に対しては, 上記の小児期に冠動脈瘤の ある症例に従う。

\section{2. 最近のエビデンス}

a. 川崎病に扔ける血管内皮機能, 慢性炎症・酸化ストレス 川崎病後遠隔期の既往児において冠動脈ないし上腕動 脈の内皮機能の低下が薬物負荷冠動脈造影, 上腕動脈工 コー検査, 寒冷刺激負荷 PETにより報告される。腕動
脈において, 冠動脈障害の有無に関わらず, 内皮機能障 害を認めると報告されている ${ }^{8)}$. 冠動脈病変を伴う例の内 皮依存性弛緩物質アセチルコリン, 内皮非依存性弛緩物 質ニトログリセリン投与による定量的冠動脈造影検查に おいて内皮機能低下を認めた9, 10). 未梢冠動脈の PETを用 いた検討では, 冠動脈病変の有無に関わりなく未梢冠動 脈の内皮機能障害を認めた.

その後多数の報告がなされ，冠動脈障害を伴う例での 内皮障害の存在は，概ね意見の一致を見ている。しかし 冠動脈障害を伴わない例に扔ける内皮機能は, 冠動脈9), 末梢動脈 10$)$ で正常との報告も見られ，必ずしも合意を得 ていない，川崎病後の内皮障害は，小児期のみではなく 成人期においても持続することが報告されている11).

内皮機能障害の機序については, 抗酸化作用を有する ビタミン Cの前投与により内皮機能障害が改善するこ と, 尿中 8-isoprostane 上昇を認めること ${ }^{12}$ から, 酸化久卜 レスの関与が推測される.さらにこれまでの報告では, 高感度 CRP 值が, 遠隔期に冠動脈病変存続例のみで上昇 すると一致した結果が得られており ${ }^{13)}$, 慢性炎症の関与 が示唆される。

b. 川崎病既往者の IVUS 所見

川崎病後遠隔期の冠動脈病変において, 退縮瘤, 冠動 脈瘤において内膜肥厚とある程度の石灰化を示唆する所 見が報告され(Fig. 1) 14-16)，特に局所性狭窄において著明 な内膜肥厚と浅在性の強い石灰化の存在が報告される. 遠隔期の内膜肥厚を示唆する所見は，急性期後に冠動脈 拡大が $4 \mathrm{~mm}$ 以上の部位で認められる17)。局所性狭窄部位 において, 概ね 6 年以上経過した場合に内腔下ないし浅 在性の石灰化が認められる。病初期から冠動脈拡大を伴 わない病変においては, 内膜肥厚を示唆する所見は稀 で, 認めても軽度である14,16,17). 成人例では, 局所性狭窄 など重症な病変ほど, 石灰化と共に均一な線維性肥厚で はない成分が認められた16) (Fig. 1).

c. 川崎病後成人期急性冠症候群の報告例

川崎病既往成人の急性冠症候群の実態に関して, イン ターネット上でアクセス可能な主に 2000 年以降の学会抄 録を検討した(Fig. 2) 7). 収集された症例は33 例で, 男性 25 例, 女性 8 例であった。年齢は 20 歳から 65 歳に及 び, 中央值 29 歳, 四分位範囲は 23〜32 歳であった。急 性期に川崎病の診断がなされている例は 15 例で, 18 例は 遠隔期に主に画像所見から川崎病既往が推定されてい た. 症例の冠動脈後遺症は, 3 枝 8 例, 2 枝 8 例, 1 枝 14 例, 0 枝 1 例であった，責任病変は，右冠動脈 14 例，前 下行枝 10 例, 左回旋枝 5 例であり, 血栓を 24 例, 有意 狭窄 16 例, 冠動脈瘤 23 例, 退縮瘤 7 例で, うち $50 \%$ 未 満狭窄を 2 例に認めた。

以上から，川崎病既往成人に打いて血栓形成を伴う急 性冠症候群の範疇と考える冠イベントは, 既に実態とし て発症しており, 若年成人に認められ，種々の冠動脈 


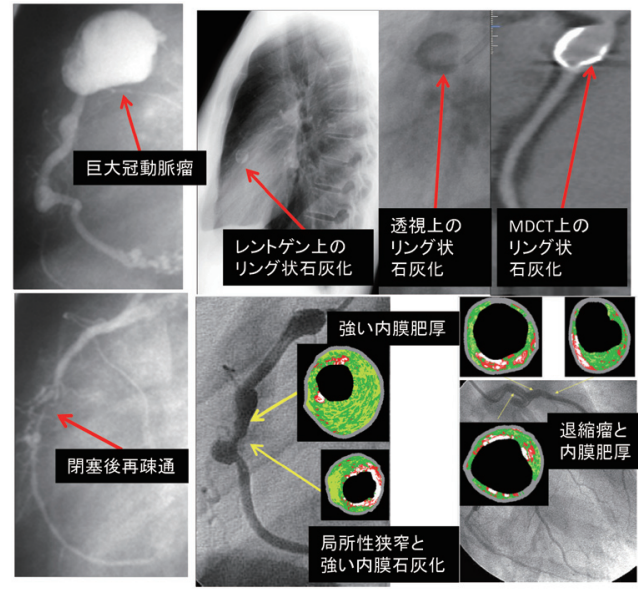

Typical findings: Giant aneurysm, Ring-like calcification Recanalization (or segmental stenosis) severe intimal thickening \& calcification

Fig. 1 Retrospective diagnosis of KD from imaging modalities in adults.

瘤, 局所性狭窄を伴うこと, 狭窄性病変の中には $50 \%$ 未 満の軽度病変も一部に認めた。成人例においては, 小児 期からの川崎病診断は必ずしもなされておらず経過観察 例は稀と考えられ，川崎病が新しい疾患であること，小 児期から成人に至る診療継続の問題によると思われる.

\section{IV. 冠後遺症なし例への考え方と対応}

\section{1. 現時点での考え方と指針}

小児科領域の川崎病後遺症の検討では, 心症状を生じ る大部分は冠動脈瘤のある症例であり, かつ陳旧期死亡 例のほぼ全例に冠動脈瘤がある. 急性期以後に正常心工 コーの患者は治療の必要はないと考えられている. しか し, 冠動脈瘤のない症例でも川崎病急性期には冠動脈瘤 のある例よりは軽度ではあるが血管炎の存在が報告さ れ，心後遺症のない例の非心事故による剖検例の検討 で, 軽度一中等度の内膜肥厚を認める報告もあり, 中年 以降に動脈硬化の進行をもたらす可能性は否定できな い. したがって, 家族・本人と主治医との協議によって 個々に対応し, 希望があれば成人期にも数年に 1 回程度 の非侵襲的な検査での経過観察をしてもよい4)。具体的な 管理として, 発症後 5 年以上経過していれば「管理不要」 としてよい，それまでは原則「E可」とする．経過観察の目 安は, 発症後 $1,2,6$ 力月後, 1 年後, および発症後 5 年 後とする. 評価は, 心電図, 心エコー, 必要に応じて胸 部レントゲンが行われ, 最終時には負荷心電図が望まし いとされる。「管理不要」とする時点で「川崎病急性期カー ド」を渡して，生活習慣病予防についてのアドバイスを行 うことが望ましい，その後の管理については，保護者(ま たは本人)との協議による.

\section{男:女 25:8 \\ 年齢 中央値 29y (quartile: 23-32 y) \\ 急性期診断あり:なし 15: 18 \\ 病変 3枝 8例、2枝 8例、1枝 14例 \\ O枝 1例 \\ 責任病変: RCA 14, LAD 10, LCX 5 \\ 血栓 : 24例、有意狭窄 16例、動脈瘤23例 \\ 退縮瘤 7例(内50\%未満狭窄2例を含)}

Fig. 2 成人期川崎病既往者の報告例 (文献 7 から抜粋)

\section{2. 最近のエビデンス}

これまでの全国的，国際的な症例集積の中で，成人期 に急性冠症候群を来した例も含めて, 病初期から正常例 において，急性冠イベントの報告は，ほとんどみられな い. しかし，日本に㧍ける通常の郙状硬化による急性心 筋梗塞は, 男性で 50 歳台以降, 女性で 60 歳以降であ り, 2010 年現在において, 日本の全川崎病既往者 272,749 名中, 30 歳台 43,544 名, 40 歳台 5,364 名, 50 歳台 125 名 と報告され ${ }^{1)}$, 川崎病既往者が一般成人より冠イベントを 来し易いかが疫学的に判明するには, 今後 20 年程度は必 要と思われる.ささに現在, これまでの web 検索からは 35 歳以上の急性冠症候群例7では, 大部分冠イベント時の 冠動脈造影所見から川崎病既往が推測された例であり, 小児期に川崎病診断された例が極めて限られている。こ のことは, 川崎病後正常冠動脈例は, 画像からは診断さ れず，過小評価される可能性を考えさせる．したがっ て, ある程度川崎病の小児期診断がなされている現在の 20 歳台が, 好発年齢に達するまでは, 病初期から冠動脈 障害のない川崎病が冠イベントを来し易いかを疫学的に 検討するには, 今後 30 年程度を要するかもしれない。 ま た別な観点からは, 現在の日本において, 35 歳未満の若 年成人男性の张状硬化による急性冠症候群が増加してい ると言われている. 文献並びに web 検索等からはその中 に病初期に冠動脈障害を伴わない川崎病既往者の報告7) は, ほとんど認められないが, 成人において川崎病既往 の確認が不確定なこと, 例え発症しても古い時代の画像 診断から急性期に正常冠動脈と判断可能かなど問題があ る.この様な点から, 川崎病カードの利用は有意義な可 能性がある. また川崎病後診療脱落防止のためには, 学 校心臟検診などの登録と再評価の機会も重要と思われる.

枵状硬化を冠イベントからではなく, 张状硬化のバ イオマーカーである内皮機能, 慢性微弱炎症(高感度 CRP ${ }^{13)}$, 酸化ストレス ${ }^{12}$, 血管組織性状を生体内で評価 できる virtual histology 血管内エコー法の横断研究の報 告16) から推測できるかもしれない.内皮機能に関して は, 病初期から冠動脈障害なし例において, 冠動脈内皮 
機能が正常と示す少数例が 1 報あるが, 異常とする報告 はなく9)，末梢血管内皮機能は，正常と異常の報告があり 一定の結論を得ていない. 高感度 CRPに扔いては, 病初 期正常例で正常範囲であった ${ }^{13)}$. Virtual histology 血管内 エコー法でも16), 病初期正常セグメントに拈いて, 明ら かな内膜肥厚を認めていない.

\section{V. おわりに}

近い将来に川崎病既往者の過半数が成人例となること が予想されている中で, 川崎病既往者の診療は, 小児科 と内科のコラボレーションが重要な時代に入っている.

本稿では, 一次診療, 内科領域でも問題となる長期経過 した川崎病既往者の諸問題について, ガイドラインに則 して概説し, 最近関心の高い成人例の急性冠症候群のリ スクと診療移行の問題, 後遺症なし例の対応について, 具体的な対応, 最近のエビデンスを報告した。 今後, 川 崎病既往者のエビデンスに基づく診療体制の構築には, 小児期から成人期にかけての絶え間ない診療体制と, 全 国規模の診療科横断的な登録研究が重要と考えられる.

\section{文献}

1）中村好一, 屋代真弓 : 疫学からみた川崎病死亡例. 循環 器内科 2011; 69: 412-420

2）自治医科大学：川崎病のページ. http://www.jichi.ac.jp/ $\mathrm{dph} / \mathrm{kawasaki.html}$

3) 日本川崎病研究会運営委員会: 川崎病の管理基準 (2002 年改訂)。日児誌 2003; 107: 166-167

4) 日本循環器学会, 日本胸部外科学会, 日本小児科学会, 日本小児循環器学会, 日本心臟病学会: 川崎病心臟血管 後遺症の診断と治療に関するガイドライン (2008 年改訂 版) http://www.j-circ.or.jp/guideline/pdf/JCS2008_ogawasy_ d.pdf

5) Newburger JW, Takahashi M, Gerber MA, et al: Diagnosis, treatment, and long-term management of Kawasaki disease: a statement for health professionals from the Committee on Rheumatic Fever, Endocarditis and Kawasaki Disease, Council on Cardiovascular Disease in the Young, American Heart Association. Circulation 2004; 110: 2747-2771

6) Kavey RE, Allada V, Daniels SR, et al: Cardiovascular risk reduction in high-risk pediatric patients: a scientific statement from the American Heart Association Expert Panel on Population and Prevention Science; the Councils on Cardiovascular Disease in the Young, Epidemiology and Prevention, Nutrition,
Physical Activity and Metabolism, High Blood Pressure Research, Cardiovascular Nursing, and the Kidney in Heart Disease; and the Interdisciplinary Working Group on Quality of Care and Outcomes Research: endorsed by the American Academy of Pediatrics. Circulation 2006; 114: 2710-2738

7) 三谷義英：川崎病と成人急性冠症候群. 循環器内科 2011; 69: 366-370

8) Dhillon R, Clarkson P, Donald AE, et al: Endothelial dysfunction late after Kawasaki disease. Circulation 1996; 94: $2103-$ 2106

9) Yamakawa R, Ishii M, Sugimura T, et al: Coronary endothelial dysfunction after Kawasaki disease: evaluation by intracoronary injection of acetylcholine. J Am Coll Cardiol 1998; 31: 1074-1080

10) Mitani $Y$, Okuda $Y$, Shimpo H, et al: Impaired endothelial function in epicardial coronary arteries after Kawasaki disease. Circulation 1997; 96: 454-461

11) Niboshi A, Hamaoka K, Sakata K, et al: Endothelial dysfunction in adult patients with a history of Kawasaki disease. Eur J Pediatr 2008; 167: 189-196

12) Hamaoka A, Hamaoka K, Yahata T, et al: Effects of HMG-CoA reductase inhibitors on continuous post-inflammatory vascular remodeling late after Kawasaki disease. J Cardiol 2010; 56: 245-253

13) Mitani Y, Sawada H, Hayakawa H, et al: Elevated levels of high-sensitivity C-reactive protein and serum amyloid-A late after Kawasaki disease: association between inflammation and late coronary sequelae in Kawasaki disease. Circulation 2005; 111: $38-43$

14) Sugimura $T$, Kato $H$, Inoue $O$, et al: Intravascular ultrasound of coronary arteries in children. Assessment of the wall morphology and the lumen after Kawasaki disease. Circulation 1994; 89: $258-265$

15) Sugimura $T$, Yokoi $H$, Sato $N$, et al: Interventional treatment for children with severe coronary artery stenosis with calcification after long-term Kawasaki disease. Circulation 1997; 96: 3928 3933

16) Mitani $Y$, Ohashi H, Sawada H, et al: In vivo plaque composition and morphology in coronary artery lesions in adolescents and young adults long after Kawasaki disease: a virtual histology-intravascular ultrasound study. Circulation 2009; 119: 2829-2836

17) Tsuda E, Kamiya T, Kimura K, et al: Coronary artery dilatation exceeding $4.0 \mathrm{~mm}$ during acute Kawasaki disease predicts a high probability of subsequent late intima-medial thickening. Pediatr Cardiol 2002; 23: 9-14 